\title{
A comparison of the use of different sources of nanoscale iron particles on the concentration of micronutrients and plasma membrane stability in sorghum
}

\author{
Sabireh Golshahi ${ }^{1}$, Ahmad Gholamalizadeh Ahangar ${ }^{1 *}$, Noshin Mir $^{2}$, Maryam Ghorbani ${ }^{1}$
}

${ }^{1}$ Soil and Water Engineering Faculty, University of Zabol, Zabol, Iran. ${ }^{2}$ Department of Chemistry, University of Zabol, Zabol, Iran.*Corresponding author: ahangar@uoz.ac.ir

\begin{abstract}
The present study aimed to evaluate the method of using iron on the physiologic characteristics of speedfeed sorghum and plasma membrane stability index (PMSI). Therefore, a factorial experiment was conducted in a completely randomized design with three replications. In addition, $\mathrm{Zn}, \mathrm{Cu}, \mathrm{Mn}$ were added to the soils before planting in order to avoid the shortage of micronutrients and find the possible effects of Fe nano materials sources on their sorption. The treatments were done based on two levels of iron including soil application $\left(0.270,0.405 \mathrm{mg} \mathrm{kg}^{-1}\right.$ of soil) and foliar application ( 0.25 and $0.5 \mathrm{~g}$ of iron per liter with control) from four compost sources including iron oxide nanoparticles, monodisperse iron oxide nanoparticles, polymeric iron oxide nanoparticles, and polymeric monodisperse iron oxide nanoparticles. The results of the interaction among the procedure, level and sources of iron indicated that the concentration of iron in shoots and the concentration of zinc in roots haves increased in polymeric iron oxide nanoparticles and monodisperse iron oxide nanoparticles at $0.270 \mathrm{mg} \mathrm{kg}^{-1}$ level while manganese concentration of shoots, and PMSI of roots were significantly increased in the treatments of polymeric monodisperse iron oxide nanoparticles and iron oxide nanoparticles at $0.405 \mathrm{mg}$ $\mathrm{kg}^{-1}$ level, compared to the control group. In foliar application of iron resources, the amount of total chlorophyll in monodisperse iron oxide nanoparticles and the percentage of PMSI of leaf, concenteration of $\mathrm{Cu}, \mathrm{Fe}$ and $\mathrm{Mn}$ of roots in polymeric monodisperse iron oxide nanoparticles have significantly increased at the level of $0.25 \mathrm{~g}$ $\mathrm{L}^{-1}$ while the concentration of $\mathrm{Zn}$ in shoots in iron oxide nanoparticles have significantly increased at level of $0.5 \mathrm{~g} \mathrm{~L}^{-1}$, in comparison to the control sample. Simple, dual, or triple interaction effects of procedure, source and level of iron were not significant in copper concentration of shoots.
\end{abstract}

Keywords: Plasma membrane stability, concentration of micro-materials, polymeric monodisperse iron oxide nanoparticles, sorghum. 


\section{Introduction}

Regarding an increase in population, the importance of agriculture for all human societies was emphasized more than any other time. The first and foremost need of any human being is food and food supply which are directly or indirectly associated with agriculture. Although iron is essential for growing plants, which is found everywhere in the Earth crust, the solubility of iron compounds in most soils prevents iron absorption by the plant and expands the signs of iron deficiency in plants (Lucena, 2006). The optimum $\mathrm{pH}$ has been reported between 5.5 to 6.5 for proper growth and the optimum absorption of iron. Therefore, a $\mathrm{pH}$ greater than 7 can lead to iron deficiency (Korcak, 1987; Bityutskii et al., 2017).

Various methods have been proposed for the removal of iron deficiency in plants such as soil application, foliar application or mixing iron with seeds (Godsey and Johnson, 2001). The use of different types of fertilizers is the main solution for the correction and maintenance of soil fertility and the increase of crop production (Rezaeei et al., 2014; Dong et al., 2016). Borowski and Michalek (2011) reported that foliar application of inorganic iron salts increases chlorophyll a, chlorophyll $\mathrm{b}$ and carotenoid of green beans. Sheykhbaglou et al., (2010) showed that the use of nanoscale iron oxide particles increase soybean yields. Ghafari and Razmjoo (2013) reported the application of iron oxide nanoparticles on chlorophyll a, chlorophyll $\mathrm{b}$ and total chlorophyll wheat showed a significant increase compared with the control. Ghafariyan et al., (2013) reported that these superparamagnetic iron oxide nanoparticles that inserted into soybean plants and then moved in them increase chlorophyll levels without creating the toxicity of micronutrients. Armin et al., (2014) found that an increase in the concentration of iron leads to an increase in wheat yield and its components.
Few studies have addressed on the herbal toxicity of nanoparticles during a complete plantation course (Rico et al., 2011). In addition, studies conducted on the toxicity of nanoparticles have paid more attention to the cultivation of plants and horticultural crops while they failed to address woody plants (Seeger et al., 2009). The effect of nanoparticles on plants, along with its toxicity has been emphasized for a few generations of plants during a long-term period. However, the determination of long-term effects of nanoparticles on plants is regarded as a neglected area (Wang et al., 2013).

In this study, we have examined the concentration of micronutrients in roots and shoots of the plants as well as the stability of the plasma membrane of the entrance of its elements and plant resistance against stress on the inner membrane of plant including the iron levels. Sullivan (1972) presented a fast and efficient method to determine cell membrane stability in grain sorghum using measuring electrolyte leakage of plant tissues which were exposed to thermal shock. This method is used as a quick, cheap and simple method to evaluate the cell membrane stability in many plants such as sorghum (Sullivan and Ross, 1979). The researches have focused on the effects of nanoscale iron particles fertilizers as well as plant yield and no study has taken into consideration the damages caused by these fertilizers and stress on the plant. This study aimed to compare the use of iron oxide nanoparticles, monodisperse iron oxide nanoparticles, polymeric iron oxide nanoparticles, polymeric monodisperse iron oxide nanoparticles on the concentration of micronutrients and plasma membrane stability of forage sorghum to find the best iron fertilizer and how to use these fertilizers with the least damage to the plasma membrane. 


\section{Material and Methods}

A greenhouse experiment was conducted on Speedfeed forage sorghum (Sorghum Bicolor (L.) Moench) in a completely randomized factorial design with three replications. The treatments included two levels of iron including soil application $(0.270$, $0.405 \mathrm{mg} \mathrm{kg}^{-1}$ of soil) and foliar application $(0.25$ and $0.5 \mathrm{~g}$ of iron per liter with control) from four compost sources such as Iron oxide nanoparticles, monodisperse Iron oxide nanoparticles, polymeric iron oxide nanoparticles, polymeric monodisperse Iron oxide nanoparticles. Soil was prepared from 0 to $30 \mathrm{~cm}$ depth of training and research greenhouses of Zabol University and after it was air-dried and passed a 2-mm sieve, some physical and chemical properties were determined including Soil $\mathrm{pH}$ and electrical conductivity, soil texture with hydrometer (Bouyoucos, 1997), cation exchange capacity (Rible and Quick, 1960), calcium carbonate equivalent titration method (U.S. Salinity Laboratory Staff, 1954), organic matter by Walkley and Black's method (Walkley and Black, 1934), the Kjeldahl method for total nitrogen (Page et al., 1982), available Phosphorus by Olsen's method (Olsen et al., 1954), the concentration of iron in the soil with extractor DTPA (Lindsay and Norvell, 1978) and was read by atomic absorption spectrometry and potassium extracted by ammonium acetate (Helmke and Sparks, 1996) were determined by flame photometer (Table 1).

Table 1. Some physical and chemical properties of soils in this study

\begin{tabular}{cccccccccc}
\hline Texture & $\mathrm{pH}$ & $\begin{array}{c}\mathrm{EC} \\
\left(\mathrm{dS} . \mathrm{m}^{-1}\right)\end{array}$ & $\begin{array}{c}\mathrm{CEC} \\
\left(\mathrm{Cmol}^{+} \mathrm{kg}^{-1}\right)\end{array}$ & $\begin{array}{c}\mathrm{OM} \\
(\%)\end{array}$ & $\begin{array}{c}\mathrm{CCE} \\
(\%)\end{array}$ & $\begin{array}{c}\mathrm{N} \\
(\%)\end{array}$ & $\mathrm{P}$ & $\mathrm{K}$ & $\mathrm{Fe}$ \\
\hline $\begin{array}{c}\text { Sandy } \\
\text { loam }\end{array}$ & 7.77 & 1.82 & 9 & 0.48 & 20.5 & 0.12 & 12.7 & 30 & 2.32 \\
\hline
\end{tabular}

Three kilograms of sieved soil were poured in plastic bags. Before planting the seeds, based on soil test and in order to avoid the possible shortage of macro and micro-materials, some materials were added to the vase such as: $75 \mathrm{mg}$ potassium per $\mathrm{kg}, 75 \mathrm{mg}$ phosphorous per $\mathrm{kg}, 150 \mathrm{mg}$ of nitrogen per $\mathrm{kg}$ in two stages, $2 \mathrm{mg}$ of copper per $\mathrm{kg}, 5 \mathrm{mg}$ of zinc per $\mathrm{kg}$, and 5 $\mathrm{mg}$ of manganese per $\mathrm{kg}$. To use iron fertilizers in soil, the desired amount of fertilizer was mixed with soil before plantation and was added to a three-kilogram vase. Five sorghum seeds were planted at a depth of about 2 to $3 \mathrm{~cm}$ in each vase and the vases were irrigated till they reach the filed capacity moisture. After about 10 days of culture, the number of plants in each vase reduced to three. Plants were watered by distilled water during growth period and in weight manner.
Foliar application of iron was performed in two stages, i.e. four-leaf stage and two weeks after the first spraying. Two months after planting, shoots were picked from the crown and then air dried. The roots were washed with distilled water and soil was gently separated. Shoots and roots were dried at $70{ }^{\circ} \mathrm{C}$ for 48 hours in the oven, then, the samples were prepared by dry ashing for the analysis of plant and herbal extracts (Motsara and Roy, 2008).

Concentration of micro-materials (iron, manganese, copper and zinc) in plant extracts was measured by atomic absorption spectrometry.Total chlorophyll was determined based on Arnon's method (1949). Plasma membrane stability index (PMSI) was measured by Sairam and Srivastava (2001) method and was calculated according to the following formula: 
PMSI $(\%)=(1-(\mathrm{C} 1 / \mathrm{C} 2)) * 100$

The experimental data were examined using SAS 9.4 statistical software and the averages were compared using Duncan's Multiple Range Tests at 0.01 and 0.05 significance level.

\section{Results}

\subsection{Characterization of nanomaterials}

Figure 1 illustrates FT-IR spectra of four employed nanoparticles in this work. FT-IR spectroscopy is a useful tool for characterization of functional groups.
Figures 1a, b, c, and d indicate iron oxide nanoparticles, monodisperse iron oxide nanoparticles, polymeric iron oxide nanoparticles, and polymeric monodisperse iron oxide nanoparticles, respectively. For "Polymeric Iron oxide nanoparticles" and "Polymeric monodisperse Iron oxide nanoparticles" which their FT-IR spectra are shown in Figure 2c and 2d, respectively, the as-prepared Iron oxide nanoparticles and monodisperse Iron oxide nanoparticles were dispersed in PEG-6000 polymer and then were characterized by FT-IR spectroscopy. Some of the characteristic peaks are representative of attachment of the PEG polymer to the surface of Iron oxide nanoparticles.

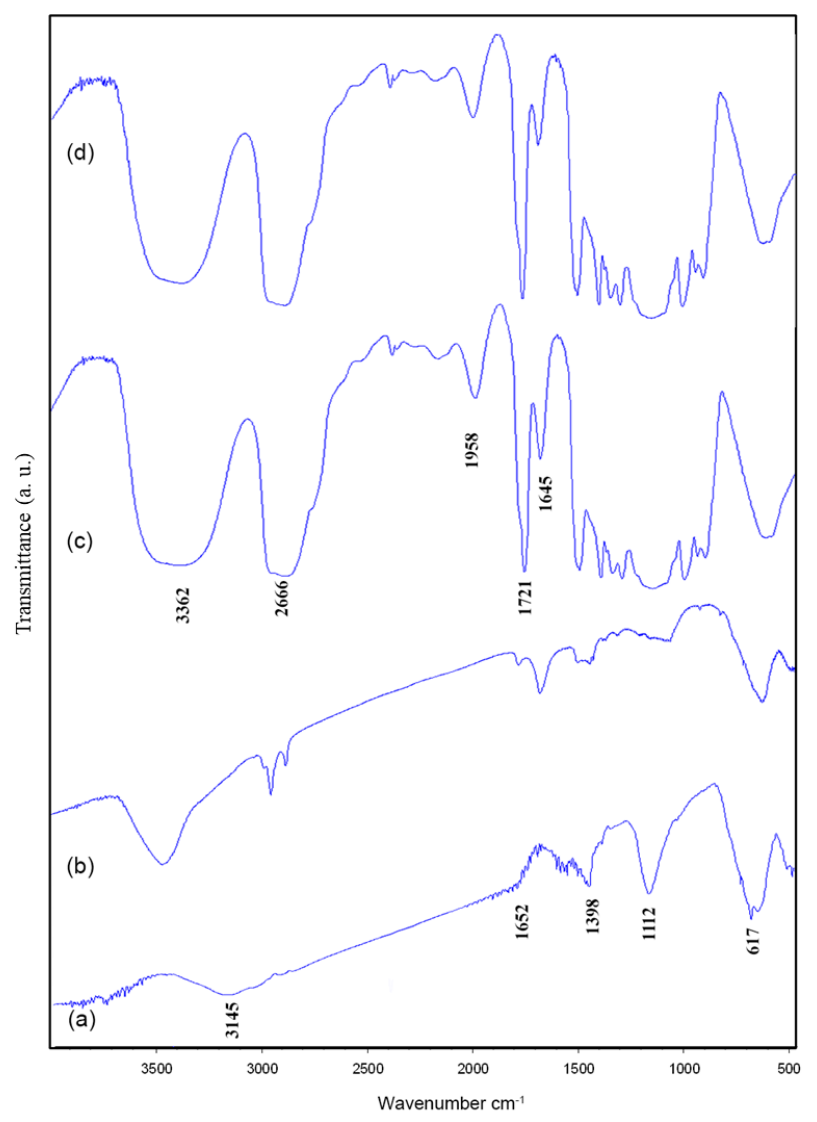

Figure 1. FT-IR spectrum of (a) Iron oxide nanoparticles; (b) Monodisperse iron oxide nanoparticles; (c) Polymeric iron oxide nanoparticles; (d) Polymeric monodisperse iron oxide nanoparticles 
In order to characterize the phase of the prepared nanoparticles, XRD patterns of iron oxide and monodisperse iron oxide nanoparticles were recorded and were shown in Figure 2a and b, respectively.

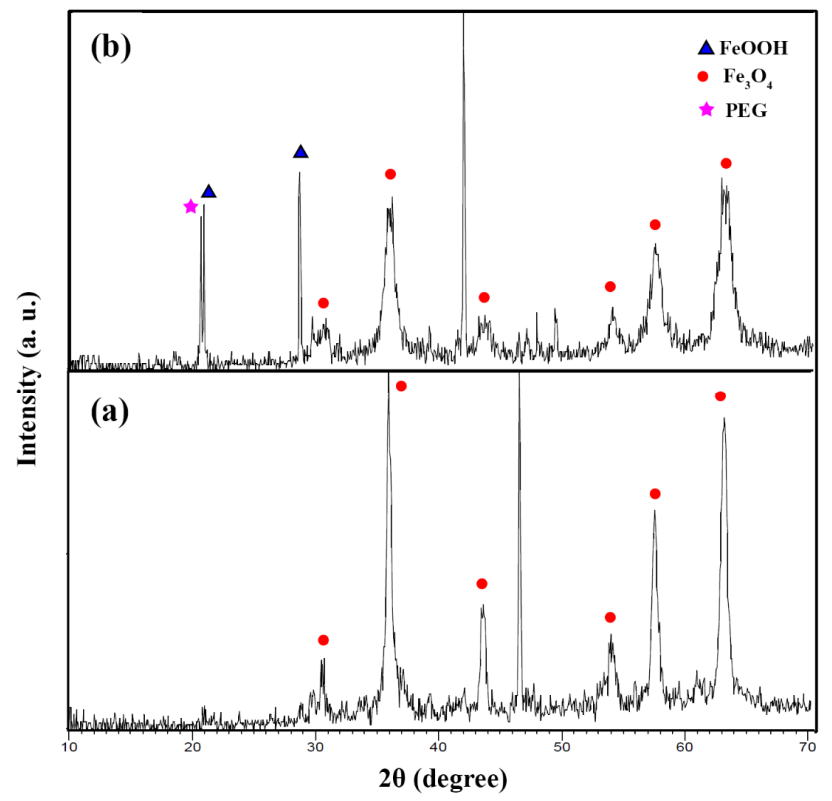

Figure 2. XRD patterns of (a) Iron oxide nanoparticles; (b) Monodisperse iron oxide nanoparticles

Figure 3 illustrates the morphology and elemental composition of the prepared nanoparticles. SEM images of iron oxide nanoparticles and monodisperse iron oxide nanoparticles are displayed in Figure 3a and b, respectively. Energy-dispersive X-ray (EDX) analysis was used to specify the type and quantitative amounts of the elements in each sample. Figure $3 \mathrm{c}$ and $\mathrm{d}$ represent the EDX analyses of iron oxide nanoparticles and monodisperse iron oxide nanoparticles, respectively. 

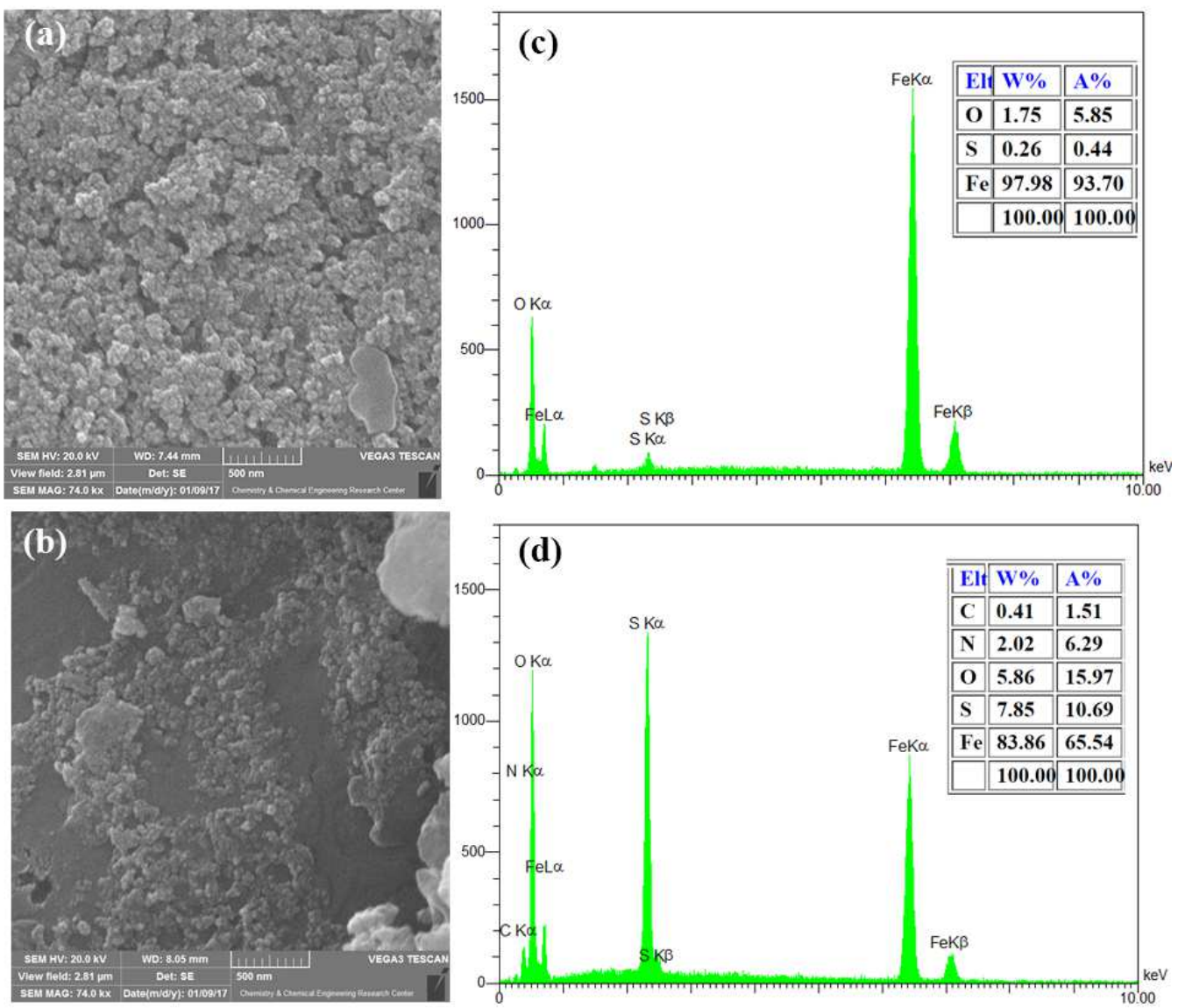

Figure 3. SEM images and EDX spectra of (a) and (c) iron oxide nanoparticles; (b) and (d) monodisperse iron oxide nanoparticles

\subsection{Characterization of plant}

Results of ANOVA in Table 2 indicated that simple effects (except level) and dual interactions of level and sources of iron and triple interactions among procedure, levels and sources of iron were significantly important at significance level of 0.05 and PMSI of leaf was significant at the level of 0.05 under the simple effects of iron sources and the effects of dual interactions (except procedure and levels) and the triple interactions of procedure, source and level of iron. Further, simple effects (except level) and the effects of dual interactions (except procedure and levels) and the effects of triple interactions of procedure, sources and level showed that total chlorophyll of leaves was significant at the 0.05 level of significance (Table 2). 
Table 2. Results of ANOVA for procedure, sources and level of iron on the quality characteristics and the concentration of micro-materials in plant roots and shoots

\begin{tabular}{|c|c|c|c|c|c|}
\hline \multirow[b]{2}{*}{ S.O.V } & \multirow[b]{2}{*}{ df } & \multicolumn{4}{|c|}{ Mean square } \\
\hline & & $\begin{array}{l}\text { PMSI of } \\
\text { root }\end{array}$ & PMSI of leaf & \multicolumn{2}{|c|}{ Total chlorophyll } \\
\hline Procedure & 1 & $278.9001 *$ & $21.5880 \mathrm{~ns}$ & \multicolumn{2}{|c|}{$24.9228 *$} \\
\hline Iron sources & 4 & $248.2164 *$ & $359.2417 *$ & \multicolumn{2}{|c|}{$11.1844^{*}$} \\
\hline Level & 1 & $0.4752 \mathrm{~ns}$ & $12.4852 \mathrm{~ns}$ & \multicolumn{2}{|c|}{$0.0183 \mathrm{~ns}$} \\
\hline Procedure*Level & 1 & $17.7561 \mathrm{~ns}$ & $1.2702 \mathrm{~ns}$ & \multicolumn{2}{|c|}{$0.5282 \mathrm{~ns}$} \\
\hline Procedure*Iron sources & 4 & $73.5357 \mathrm{~ns}$ & $198.3990^{*}$ & \multicolumn{2}{|c|}{$8.4408^{*}$} \\
\hline Level*Iron sources & 4 & $252.2203^{*}$ & $106.4792 *$ & \multicolumn{2}{|c|}{$2.3761 *$} \\
\hline $\begin{array}{l}\text { Procedure*Level*Iron } \\
\text { sources }\end{array}$ & 4 & $946.2491 *$ & $79.4955^{*}$ & \multicolumn{2}{|c|}{$7.1568^{*}$} \\
\hline Error & 40 & 15.1639 & 1.8747 & \multicolumn{2}{|c|}{0.1190} \\
\hline C.V. $(\%)$ & - & 12.6311 & 9.3112 & \multicolumn{2}{|c|}{7.6412} \\
\hline \multirow[b]{2}{*}{ S.O.V } & \multirow[b]{2}{*}{ df } & \multicolumn{4}{|c|}{ Mean square } \\
\hline & & $\begin{array}{c}\mathrm{Cu} \\
\text { content in } \\
\text { shoots }\end{array}$ & $\begin{array}{l}\text { Fe content in } \\
\text { shoots }\end{array}$ & $\begin{array}{c}\text { Mn } \\
\text { content in } \\
\text { shoots }\end{array}$ & $\begin{array}{c}\mathrm{Zn} \\
\text { content in } \\
\text { shoots }\end{array}$ \\
\hline Procedure & 1 & $0.0365 \mathrm{~ns}$ & 754.6597* & $12.9828^{*}$ & $47.4904 *$ \\
\hline Iron sources & 4 & $0.5334 \mathrm{~ns}$ & $3390.8192 *$ & $13.3382 *$ & $39.3494 *$ \\
\hline Level & 1 & $0.6448 n s$ & $1746.6852 *$ & $4.0093^{*}$ & $8.8627 *$ \\
\hline Procedure*Level & 1 & $0.8401 \mathrm{~ns}$ & $2780.5233^{*}$ & $5.8593 *$ & $174.2169 *$ \\
\hline Procedure*Iron sources & 4 & $0.1294 \mathrm{~ns}$ & $2369.4607^{*}$ & $6.8951 *$ & $132.5607^{*}$ \\
\hline Level*Iron sources & 4 & $0.6209 \mathrm{~ns}$ & $2133.6880^{*}$ & $5.5170^{*}$ & $120.9008^{*}$ \\
\hline $\begin{array}{l}\text { Procedure*Level*Iron } \\
\text { sources }\end{array}$ & 4 & $0.3793 \mathrm{~ns}$ & $2433.2811^{*}$ & $0.8246^{*}$ & $65.8066^{*}$ \\
\hline Error & 40 & 0.2410 & 0.3732 & 0.0184 & 0.2465 \\
\hline C.V. $(\%)$ & - & 13.2001 & 1.6134 & 2.9140 & 4.3988 \\
\hline \multirow[b]{2}{*}{ S.O.V } & & \multicolumn{4}{|c|}{ Mean square } \\
\hline & df & $\begin{array}{c}\mathrm{Cu} \\
\text { content in } \\
\text { roots }\end{array}$ & $\begin{array}{l}\text { Fe content in } \\
\text { roots }\end{array}$ & $\begin{array}{l}\mathrm{Mn} \\
\text { content in } \\
\text { roots }\end{array}$ & $\begin{array}{c}\mathrm{Zn} \\
\text { content in } \\
\text { roots }\end{array}$ \\
\hline Procedure & 1 & $13.2634^{*}$ & $16887.7282 *$ & $150.8603^{*}$ & $24.2316^{*}$ \\
\hline Iron sources & 4 & $1.2963 *$ & $143325.7411 *$ & $403.4397 *$ & $585.0356^{*}$ \\
\hline Level & 1 & $7.3290 *$ & $127161.5599 *$ & $309.9917 *$ & $598.1883^{*}$ \\
\hline Procedure*Level & 1 & $0.0686 \mathrm{~ns}$ & $10701.0944 *$ & $159.2184 *$ & $926.7726^{*}$ \\
\hline Procedure*Iron sources & 4 & $1.6021 \mathrm{~ns}$ & $58616.4719^{*}$ & $442.2122 *$ & $955.0887^{*}$ \\
\hline Level*Iron sources & 4 & $2.6732 *$ & $126076.1516^{*}$ & $596.2099 *$ & $783.0423^{*}$ \\
\hline $\begin{array}{l}\text { Procedure*Level*Iron } \\
\text { sources }\end{array}$ & 4 & $0.5422 *$ & $68174.5962 *$ & $353.3202 *$ & $802.6822 *$ \\
\hline Error & 40 & 0.2495 & 0.340 & 0.2525 & 0.2462 \\
\hline C.V. $(\%)$ & - & 13.9477 & 0.0856 & 2.0925 & 3.7450 \\
\hline
\end{tabular}

(*and $* *$ denoted significance at the 5 and 1 percent level, respectively; ns is not significant).

Results of ANOVA in Table 2 indicated that simple effects, the effects of dual interactions and the effects of triple interactions of procedure, sources and level on the concentrations of iron, manganese and zinc were significant at the level of 0.05 in shoots but it was not meaningful for copper concentration of shoots. As shown in Table 2, ANOVA results indicated that simple effects, the effects of dual interactions and those of triple interactions among procedure, sources and level on the concentrations of iron, manganese and zinc were significant at level of 0.05 in roots. Further, results of ANOVA for the simple effect, dual interaction of iron level and sources, and triple interactions of iron procedure, sources and level on the concentration of copper were significant $(\mathrm{P}<0.05)$ (Table 2). 
Table 3. Results of the comparison of the mean effects of triple interaction of procedure, source and level of iron on PMSI of leaf and root and total chlorophyll

\begin{tabular}{|c|c|c|c|c|c|}
\hline Procedure & Level & Treatment & $\begin{array}{l}\text { PMSI of } \\
\text { root }(\%)\end{array}$ & $\begin{array}{l}\text { PMSI of } \\
\text { leaf }(\%)\end{array}$ & $\begin{array}{l}\text { Total chlorophyll } \\
\text { (mg g }{ }^{-1} \text { fresh } \\
\text { weight })\end{array}$ \\
\hline \multirow{9}{*}{$\begin{array}{c}\text { Soil } \\
\text { application }\end{array}$} & 0 & Control & $15.19 \mathrm{e}$ & $5.87 \mathrm{j}$ & $3.94 \mathrm{ef}$ \\
\hline & & Iron oxide nanoparticles & $14.32 \mathrm{e}$ & $21.81 \mathrm{c}$ & $3.02 \mathrm{ghi}$ \\
\hline & Tox & Monodisperse iron oxide nanoparticles & $31.53 \mathrm{c}$ & $25.13 b$ & $3.49 f g$ \\
\hline & $\stackrel{60}{g}$ & Polymeric Iron oxide nanoparticles & $17.56 \mathrm{e}$ & $15.20 \mathrm{de}$ & $3.09 \mathrm{gh}$ \\
\hline & 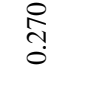 & $\begin{array}{c}\text { Polymeric monodisperse Iron oxide } \\
\text { nanoparticles }\end{array}$ & $40.59 \mathrm{a}$ & 11.63ghi & $6.34 \mathrm{c}$ \\
\hline & & Iron oxide nanoparticles & $41.26 \mathrm{a}$ & $17.61 \mathrm{~d}$ & $4.32 \mathrm{de}$ \\
\hline & To & Monodisperse iron oxide nanoparticles & $24.23 \mathrm{~d}$ & $24.05 \mathrm{bc}$ & $4.61 d$ \\
\hline & $\stackrel{60}{\Xi}$ & Polymeric Iron oxide nanoparticles & $33.68 \mathrm{bc}$ & 16.18de & $3.88 \mathrm{ef}$ \\
\hline & $\begin{array}{l}\mathscr{6} \\
\stackrel{0}{+} \\
0\end{array}$ & $\begin{array}{c}\text { Polymeric monodisperse Iron oxide } \\
\text { nanoparticles }\end{array}$ & $11.54 \mathrm{e}$ & $9.18 \mathrm{i}$ & $2.40 \mathrm{i}$ \\
\hline \multirow{9}{*}{ Spraying } & 0 & Control & $15.19 \mathrm{e}$ & $5.87 \mathrm{j}$ & $3.94 \mathrm{ef}$ \\
\hline & & Iron oxide nanoparticles & $15.00 \mathrm{e}$ & $12.54 \mathrm{fgh}$ & $6.32 \mathrm{c}$ \\
\hline & $\widetilde{F}$ & Monodisperse iron oxide nanoparticles & $30.37 \mathrm{~cd}$ & 10.93hi & $7.92 \mathrm{a}$ \\
\hline & 0 & Polymeric Iron oxide nanoparticles & $30.72 \mathrm{~cd}$ & 11.78 fghi & $2.80 \mathrm{hi}$ \\
\hline & ֻั & $\begin{array}{c}\text { Polymeric monodisperse Iron oxide } \\
\text { nanoparticles }\end{array}$ & $10.91 \mathrm{e}$ & $30.95 \mathrm{a}$ & $4.25 \mathrm{de}$ \\
\hline & \multirow{4}{*}{ 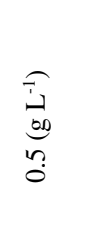 } & Iron oxide nanoparticles & $16.29 \mathrm{e}$ & 10.10hi & $7.30 \mathrm{~b}$ \\
\hline & & Monodisperse iron oxide nanoparticles & $14.32 \mathrm{e}$ & $24.37 \mathrm{~b}$ & $6.19 \mathrm{c}$ \\
\hline & & Polymeric Iron oxide nanoparticles & $13.87 \mathrm{e}$ & $14.34 \mathrm{ef}$ & $3.23 \mathrm{gh}$ \\
\hline & & $\begin{array}{l}\text { Polymeric monodisperse Iron oxide } \\
\text { nanoparticles }\end{array}$ & $38.85 \mathrm{ab}$ & $14.05 \mathrm{efg}$ & $5.83 \mathrm{c}$ \\
\hline
\end{tabular}

(means with the same letters in each column are not significantly different $(\mathrm{p}<0.01)$ ).

A comparison of the mean effects of triple interactions of procedure, sources and level of iron showed that the highest percentage of PMSI of root (the lowest membrane damage) was related to the concentration of iron oxide nanoparticles $0.405 \mathrm{mg} \mathrm{kg}^{-1}(41.26 \%)$ in the soil application of fertilizers which increased 2.71 times compared to the control (15.19\%) (Table 3). In spraying, in $0.5 \mathrm{~g} \mathrm{~L}^{-1}$ concentration, the highest percentage of PMSI of root was related to the polymeric mono- disperse iron oxide nanoparticles (38.85\%) which significantly increased, compared to the control, but no significant difference was observed, compared to the soil application of fertilizers (Table 3). The lowest amount of PMSI of root (10.91\%) was observed in application of spraying and in the concentration of polymeric monodisperse iron oxide nanoparticles at $0.25 \mathrm{~g}$ $\mathrm{L}^{-1}$ concentration of, decreased to $39.23 \%$, compared to the control (Table 3). 
A comparison of the results of mean effects of triple interactions of procedure, sources and level of iron in Table 3 showed that the highest percentage of PMSI of leaf (the lowest membrane damage) was related to the polymeric monodisperse iron oxide nanoparticles (30.95\%) in the application of spraying fertilizers at the concentration of $0.25 \mathrm{~g} \mathrm{~L}^{-1}$, increased 5.27 times with the highest membrane damage (the lowest percentage of PMSI of leaf), compared to the control $(5.87 \%)$ (Table 3$)$. In soil application of fertilizers, the highest percent of PMSI of leaves (25.13\%) was related to monodisperse iron oxide nanoparticles at the concentration of $0.270 \mathrm{mg} \mathrm{kg}^{-1}$ which showed a significant increase, compared to the control group as well as a the use of fertilizers (Table 3). Based on the comparison of mean effects of triple interactions of procedure, sources and level of iron (Table 3), the highest amount of total chlorophyll in the use of spraying of 0.25 gram per liter was observed in monodisperse iron oxide nanoparticles (7.92 $\mathrm{mg} \mathrm{g}^{-1}$ ), which was significantly increased, compared to the control (3.94 $\mathrm{mg} \mathrm{g}^{-1}$ ). Also, the highest amount of total chlorophyll was obsereved in iron oxide nanoparticles at the use of spraying $0.5 \mathrm{~g} \mathrm{~L}^{-1}$. The lowest amount of total chlorophyll was observed in polymeric monodisperse iron oxide nanoparticles in the soil application of $0.405 \mathrm{mg} \mathrm{kg}^{-1}$ of iron and was significantly different compared to control (Table 3).

Based on the results of comparing the mean triple interaction of procedure, sources and level (Table 4), the highest concentration of iron in shoots was observed in polymeric iron oxide nanoparticles $\left(56.10 \mathrm{mg} \mathrm{kg}^{-1}\right)$ at the level of $0.270 \mathrm{mg} \mathrm{kg}^{-1}$, increased 1.5 times, compared to the control $\left(28.79 \mathrm{mg} \mathrm{kg}^{-1}\right)$. Further, polymeric monodisperse iron oxide nanoparticles (44.79 $\mathrm{mg} \mathrm{kg}^{-1}$ ) had the highest increase at the $0.25 \mathrm{~g} \mathrm{~L}^{-1}$, indicating the most significant concentration of iron in shoots (Table 4). The results of comparison of mean effects of triple interactions of procedure, sources and level of iron (Table 4) indicated that the lowest concentartion of manganese in the soil application of iron sources was observed in monodisperse iron oxide nanoparticles (3.21 $\mathrm{mg} \mathrm{g}^{-1}$ ), which significantly reduced, compared to the control (44.23\%).

The highest concentration of Manganese in the soil application of shoot is polymeric monodisperse iron oxide nanoparticles $\left(9.68 \mathrm{mg} \mathrm{kg}^{-1}\right)$ at the level of $0.405 \mathrm{mg} \mathrm{kg}^{-1}$, which significantly increased 2.09 times, compared to the control $\left(4.63 \mathrm{mg} \mathrm{kg}^{-1}\right)$.

According to the results of comparing the mean triple interaction of procedure, sources and level of iron (Table 4), the highest concentration of zinc in shoots was observed in iron oxide nanoparticles (25.83 $\left.\mathrm{mg} \mathrm{kg}^{-1}\right)$ at the level of $0.5 \mathrm{~g} \mathrm{~L}^{-1}$, which increased 2.87 times, compared to the control $(8.98 \mathrm{mg}$ $\mathrm{kg}^{-1}$ ). Among the sources of iron that were used to soil application, the highest amount of zinc on shoot was observed in polymeric monodisperse iron oxide nanoparticles $\left(21.63 \mathrm{mg} \mathrm{kg}^{-1}\right)$ at level of iron of $0.270 \mathrm{mg} \mathrm{kg}^{-1}$ (Table 4).

The lowest concentration of zinc $\left(7.22 \mathrm{mg} \mathrm{kg}^{-1}\right)$ in plant shoot in the use of spraying was observed in the treatment of polymeric iron oxide nanoparticles at the level of $0.5 \mathrm{~g} \mathrm{~L}^{-1}$ and was significantly reduced, compared to the control (Table 4). Simple, dual and triple interactions effects of procedure, source and level of iron were not significant in copper concentration of shoots of sorghum (Table 2). 
Table 4. The results of the comparison of mean effects of triple interaction of procedure, source and level of iron on the concentration of iron, manganese and zinc in shoot

\begin{tabular}{|c|c|c|c|c|c|}
\hline \multirow{2}{*}{ Procedure } & \multirow{2}{*}{ Level } & \multirow{2}{*}{ Treatment } & $\mathrm{Fe}$ & $\mathrm{Mn}$ & $\mathrm{Zn}$ \\
\hline & & & \multicolumn{3}{|c|}{$\mathrm{mg} \mathrm{kg}^{-1}$} \\
\hline \multirow{9}{*}{$\begin{array}{c}\text { Soil } \\
\text { application }\end{array}$} & 0 & Control & $28.79 \mathrm{j}$ & $4.63 \mathrm{~g}$ & $8.98 \mathrm{e}$ \\
\hline & 9 & Iron oxide nanoparticles & $29.21 \mathrm{j}$ & $3.94 \mathrm{i}$ & $9.55 \mathrm{de}$ \\
\hline & top & Monodisperse iron oxide nanoparticles & $29.36 j$ & 3.211 & $8.60 \mathrm{ef}$ \\
\hline & $\stackrel{\infty}{\Xi}$ & Polymeric Iron oxide nanoparticles & $56.10 \mathrm{a}$ & $5.05 \mathrm{e}$ & $9.52 \mathrm{de}$ \\
\hline & 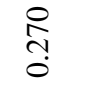 & $\begin{array}{l}\text { Polymeric monodisperse Iron oxide } \\
\text { nanoparticles }\end{array}$ & $33.10 \mathrm{~h}$ & $6.37 b$ & $21.63 b$ \\
\hline & & Iron oxide nanoparticles & $28.72 \mathrm{j}$ & $3.63 \mathrm{j}$ & $8.79 \mathrm{e}$ \\
\hline & Top & Monodisperse iron oxide nanoparticles & $33.58 \mathrm{~h}$ & $4.73 \mathrm{f}$ & $9.59 \mathrm{de}$ \\
\hline & $\stackrel{\infty}{\Xi}$ & Polymeric Iron oxide nanoparticles & $34.42 \mathrm{~g}$ & $6.26 c$ & $7.73 \mathrm{fg}$ \\
\hline & \begin{tabular}{l}
$n$ \\
\multirow{o}{+}{} \\
0
\end{tabular} & $\begin{array}{l}\text { Polymeric monodisperse Iron oxide } \\
\text { nanoparticles }\end{array}$ & $39.68 \mathrm{~d}$ & $9.68 \mathrm{a}$ & $10.35 d$ \\
\hline \multirow{9}{*}{ Spraying } & 0 & Control & $28.79 \mathrm{j}$ & $4.63 \mathrm{~g}$ & $8.98 \mathrm{e}$ \\
\hline & & Iron oxide nanoparticles & $31.42 \mathrm{i}$ & $4.16 \mathrm{~h}$ & $9.55 \mathrm{de}$ \\
\hline & $\widetilde{T}$ & Monodisperse iron oxide nanoparticles & $31.00 \mathrm{i}$ & $4.73 \mathrm{f}$ & $9.25 \mathrm{e}$ \\
\hline & क्र & Polymeric Iron oxide nanoparticles & $35.52 \mathrm{f}$ & $4.10 \mathrm{~h}$ & $15.15 \mathrm{c}$ \\
\hline & ֶָ? & $\begin{array}{l}\text { Polymeric monodisperse Iron oxide } \\
\text { nanoparticles }\end{array}$ & $44.79 b$ & $3.63 \mathrm{j}$ & $7.73 \mathrm{fg}$ \\
\hline & \multirow{4}{*}{ 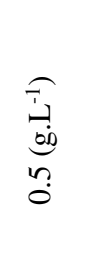 } & Iron oxide nanoparticles & $35.73 \mathrm{f}$ & $3.37 \mathrm{k}$ & $25.83 a$ \\
\hline & & Monodisperse iron oxide nanoparticles & $37.15 \mathrm{e}$ & $3.42 \mathrm{k}$ & $21.89 \mathrm{~b}$ \\
\hline & & Polymeric Iron oxide nanoparticles & $40.89 c$ & $3.58 \mathrm{j}$ & $7.22 \mathrm{~g}$ \\
\hline & & $\begin{array}{l}\text { Polymeric monodisperse Iron oxide } \\
\text { nanoparticles }\end{array}$ & $36.63 \mathrm{e}$ & $6.05 \mathrm{~d}$ & $7.36 \mathrm{~g}$ \\
\hline
\end{tabular}

(means with the same letters in each column are not significantly different $(p<0.01)$ ).

With regard to the comparison of the mean for triple interaction of procedure, sources and level of iron (Table 5), the results showed that the highest concentration of copper in roots $\left(5.68 \mathrm{mg} \mathrm{kg}^{-1}\right)$ was observed in polymeric monodisperse iron oxide nanoparticles at the level of $0.25 \mathrm{~g} \mathrm{~L}^{-1}$, and it has signifcantly increased, compared to the control $\left(2.63 \mathrm{mg} \mathrm{kg}^{-1}\right)$. 
Table 5. The results of the comparison of mean effects for triple interaction of procedure, source and level of iron on the concentration of copper, iron, manganese and zinc in root

\begin{tabular}{|c|c|c|c|c|c|c|}
\hline \multirow{2}{*}{ Procedure } & \multirow{2}{*}{ Level } & \multirow{2}{*}{ Treatment } & $\mathrm{Cu}$ & $\mathrm{Fe}$ & $\mathrm{Mn}$ & $\mathrm{Zn}$ \\
\hline & & & \multicolumn{4}{|c|}{$\mathrm{Mg} \mathrm{kg}^{-1}$} \\
\hline \multirow{9}{*}{$\begin{array}{c}\text { Soil } \\
\text { application }\end{array}$} & 0 & Control & 2.63cdefgh & $677.15 \mathrm{j}$ & $19.94 \mathrm{~h}$ & $6.93 \mathrm{ij}$ \\
\hline & \multirow{4}{*}{ 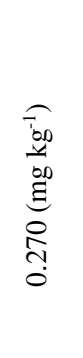 } & Iron oxide nanoparticles & $2.47 \mathrm{defgh}$ & $339.15 q$ & $24.52 \mathrm{f}$ & $8.66 \mathrm{gh}$ \\
\hline & & $\begin{array}{l}\text { Monodisperse iron oxide } \\
\text { nanoparticles }\end{array}$ & $2.42 \mathrm{efgh}$ & 527.681 & $17.58 \mathrm{ij}$ & $75.20 \mathrm{a}$ \\
\hline & & $\begin{array}{l}\text { Polymeric Iron oxide } \\
\text { nanoparticles }\end{array}$ & $2.79 \mathrm{bcdefg}$ & $875.42 \mathrm{c}$ & $30.42 \mathrm{c}$ & 7.86hi \\
\hline & & $\begin{array}{l}\text { Polymeric monodisperse Iron } \\
\text { oxide nanoparticles }\end{array}$ & $3.47 \mathrm{bcd}$ & $744.47 \mathrm{~h}$ & $22.94 \mathrm{~g}$ & $5.90 \mathrm{k}$ \\
\hline & \multirow{4}{*}{ 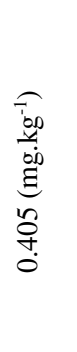 } & Iron oxide nanoparticles & 2.00fgh & $791.15 \mathrm{~g}$ & 13.151 & $7.82 \mathrm{hi}$ \\
\hline & & $\begin{array}{l}\text { Monodisperse iron oxide } \\
\text { nanoparticles }\end{array}$ & $1.89 \mathrm{gh}$ & $709.89 \mathrm{i}$ & $28.73 d$ & 3.491 \\
\hline & & $\begin{array}{l}\text { Polymeric Iron oxide } \\
\text { nanoparticles }\end{array}$ & $1.73 \mathrm{~h}$ & $892.84 b$ & $33.63 b$ & $6.31 \mathrm{jk}$ \\
\hline & & $\begin{array}{l}\text { Polymeric monodisperse Iron } \\
\text { oxide nanoparticles }\end{array}$ & $1.84 \mathrm{gh}$ & $402.31 \mathrm{p}$ & 13.361 & $9.46 \mathrm{fg}$ \\
\hline \multirow{9}{*}{ Spraying } & 0 & Control & $2.63 \mathrm{cdefgh}$ & $677.15 \mathrm{j}$ & $19.94 \mathrm{~h}$ & $6.93 \mathrm{ij}$ \\
\hline & \multirow{4}{*}{ 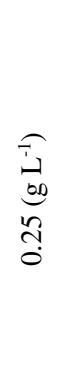 } & Iron oxide nanoparticles & $3.52 \mathrm{bc}$ & $662.00 \mathrm{k}$ & $18.36 \mathrm{i}$ & $21.48 \mathrm{c}$ \\
\hline & & $\begin{array}{l}\text { Monodisperse iron oxide } \\
\text { nanoparticles }\end{array}$ & $2.97 \mathrm{bcdef}$ & $460.42 \mathrm{o}$ & $14.94 \mathrm{k}$ & $7.59 \mathrm{i}$ \\
\hline & & $\begin{array}{l}\text { Polymeric Iron oxide } \\
\text { nanoparticles }\end{array}$ & $3.79 \mathrm{~b}$ & $841.42 d$ & $28.21 \mathrm{~d}$ & $9.65 \mathrm{f}$ \\
\hline & & $\begin{array}{l}\text { Polymeric monodisperse Iron } \\
\text { oxide nanoparticles }\end{array}$ & $5.68 \mathrm{a}$ & $1007.94 a$ & $66.05 a$ & $13.60 d$ \\
\hline & \multirow{4}{*}{ 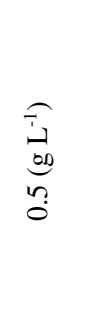 } & Iron oxide nanoparticles & $3.63 b c$ & $793.10 f$ & $26.68 \mathrm{e}$ & $29.16 b$ \\
\hline & & $\begin{array}{l}\text { Monodisperse iron oxide } \\
\text { nanoparticles }\end{array}$ & $2.94 \mathrm{bcdef}$ & $517.79 n$ & 14.001 & $9.12 \mathrm{fg}$ \\
\hline & & $\begin{array}{l}\text { Polymeric Iron oxide } \\
\text { nanoparticles }\end{array}$ & $3.36 \mathrm{bcde}$ & $810.47 \mathrm{e}$ & $30.94 \mathrm{c}$ & $12.31 \mathrm{e}$ \\
\hline & & $\begin{array}{l}\text { Polymeric monodisperse Iron } \\
\text { oxide nanoparticles }\end{array}$ & $2.68 \mathrm{cdefgh}$ & $524.63 \mathrm{~m}$ & $16.94 j$ & $9.30 \mathrm{fg}$ \\
\hline
\end{tabular}

(means with the same letters in each column are not significantly different $(\mathrm{p}<0.01)$ ). 
The lowest concentration of copper in roots was observed in polymeric iron oxide nanoparticles $(1.73$ $\mathrm{mg} \mathrm{kg}-1$ ) at the level of $0.405 \mathrm{mg} \mathrm{kg}^{-1}$, which failed to have a significant difference, compared to that of the control (Table 5).

As shown in Table 5, the results indicated that the highest concentration of iron in roots $(1007.94 \mathrm{mg}$ $\mathrm{kg}^{-1}$ ) was observed in polymeric monodisperse iron oxide nanoparticles at the level of $0.25 \mathrm{~g} \mathrm{~L}^{-1}$, and it has signifcantly increased compared to control (677.15 $\mathrm{mg} \mathrm{kg}^{-1}$ ).

The lowest concentration of iron and manganese in the roots in the treatment of iron oxide nanoparticles (339.15 and $13.15 \mathrm{mg} \mathrm{kg}^{-1}$, respectively) in the soil application was observed in the soil application of iron at the level of $0.270 \mathrm{mg} \mathrm{kg}^{-1}$ and $0.405 \mathrm{mg} \mathrm{kg}^{-1}$, which have significantly reduced, compared to that of the control (99.66\% and 51.63\%, respectively) (Table 5). Based on the mean comparison of triple interaction of procedure, sources and level of iron (Table 5), the results showed that the highest concentration of manganese in roots $\left(66.5 \mathrm{mg} \mathrm{kg}^{-1}\right)$ was observed in polymeric monodisperse iron oxide nanoparticles at the level of $0.25 \mathrm{~g} \mathrm{~L}^{-1}$, and it has signifcantly increased, compared to the control (19.94 $\left.\mathrm{mg} \mathrm{kg}{ }^{-1}\right)$. Although in the treatment of polymeric monodisperse iron oxide nanoparticles, one can observe the highest concentration of copper, iron and manganese in the root (Table 5), the most damage to membrane can be observed at the root of plant (Table 3).

As it is evident from Table 5, the highest concentration of zinc in roots was observed in soil application of monodisperse iron oxide nanoparticles $(75.20 \mathrm{mg}$ $\mathrm{kg}^{-1}$ ) at the level of $0.270 \mathrm{mg} \mathrm{kg}^{-1}$, and it was found it had increased 10.85 times compared to that of the control $\left(6.93 \mathrm{mg} \mathrm{kg}^{-1}\right)$. The lowest concentration of zinc in the root was observed in monodisperse iron oxide nanoparticles $\left(3.49 \mathrm{mg} \mathrm{kg}^{-1}\right)$ in soil application in $0.405 \mathrm{mg} \mathrm{kg}^{-1}$, which was significantly reduced, compared to the control.

\section{Discussions}

\subsection{Characterization of nanomaterials}

As shown in Figure 2, the peaks appeared at 550-650 $\mathrm{cm}^{-1}$ are assigned to $\mathrm{Fe}-\mathrm{O}$ bonds of $\mathrm{Fe}_{3} \mathrm{O}_{4}$ lattice in all the stpecra for the FT-IR characterization. The peaks at around $3100-3400 \mathrm{~cm}^{-1}$ as well as the appeared peaks at $1652 \mathrm{~cm}^{-1}$ are due to the stretching and bending vibration of either water molecules present in $\mathrm{KBr}$ or the $\mathrm{OH}$ groups of PEG polymer around Iron oxide nanoparticles, respectively. The difference between "iron oxide nanoparticles" and "Monodisperse iron oxide nanoparticles" samples is in their synthetic procedure in which for the former no additive except that iron salts and $\mathrm{NaOH}$ is added and for the latter, in addition to the mentioned materials, PEG 8000 is used in the synthetic procedure. Therefore, it is expected that some characteristic peaks attributing to PEG8000 is appeared in the FT-IR spectrum of "Monodisperse iron oxide nanoparticles" (Figure 2b). As can be seen in Figure $2 b$, there are vibrations around 2800 and $2900 \mathrm{~cm}^{-1}$ which can be attributed to the C-H stretching bands of the polymer. In a study, Dang et al., (2011) reported the interaction between the PEG 6000 and $\mathrm{Cu}$ nanoparticles. They observed that two absorption peaks appear at 1690 and $1760 \mathrm{~cm}^{-1}$ after attachment of the polymer to the copper nanoparticles. Here, these two characteristic peaks are appeared at 1645 and $1715 \mathrm{~cm}^{-1}$. Therefore, attachment of PEG-6000 polymer to Iron oxide nanoparticles is confirmed for both samples (Figure 2c and d).

The observed diffraction peaks in XRD pattern of both samples are in good agreement with that of pure cubic spinel structure for magnetite (JCPDS Card No.: 19-629) (Figure 2a and b). For monodisperse 
iron oxide nanoparticles (Figure $2 b$ ), in addition to the pure Iron oxide nanoparticles, some other peaks are also observed which are representative of some impurities which mainly correspond to $\gamma$-FeOOH phase. Also a peak at $2 \theta=19$ is observed which could be attributed to PEG-8000 which was used during the synthesis of Iron oxide nanoparticles (Figure 2b). These results show that the main phase of the employed nanoparticles is cubic Iron oxide nanoparticles.

As illustrated in Figure 3a and b, based on the results of SEM images, the iron oxide nanoparticles (Figure 3a) prepared without adding any surfactant or polymer are more agglomerated than monodisperse iron oxide nanoparticles (Figure 3b) prepared in the presence of PEG-8000.

Figure $3 \mathrm{c}$ and $3 \mathrm{~d}$ show EDX analyses of iron oxide nanoparticles and monodisperse iron oxide nanoparticles, respectively. It can be seen that for monodisperse iron oxide nanoparticles, in addition to iron and oxygen, carbon is also found which confirms the existence of the residue of the applied polymer during the synthesis.

\subsection{Characterization of plant}

4.2.1. The effect of iron sources on the PMSI of root, leaf, and total chlorophyll

Based on the results in Table 3, using two different levels of iron sources and procedure can play a positive effect on root PMSI. In other words, an increase in the root PMSI leads to less damage in plant root. In the present study, an increase of root PMSI was observed in addition to increasing the root PMSI at $0.405 \mathrm{mg} \mathrm{kg}^{-1}$ of iron oxide nanoparticles although no significant difference was observed, compared to the control sample. This amount of decrease in PMSI of root caused a high damage to the plasma membrane of roots and it can be reason for the observed high concentration of copper, iron and manga- nese in the root which will be further discussed (Table 5). It was found that under stress, Plasmalma is of the first organ that is damaged (Levitt, 1980). As a result of damage to the cell membrane, the permeability has increased; therefore, electrolyte leakage from the cell caused plant wilting (Blume and Ebercon, 1981).

Table 3 displays the positive effect of the iron sources on the leaf PMSI. Based on the results, the leaf PMSI can increase by 5.27 times, compared to the control sample which indicates a lower level of damage in the leaf plasma membrane. The highest PMSI value of leaf is observed in polymeric monodispersed iron oxide nanoparticles at $0.25 \mathrm{~g} \mathrm{~L}^{-1}$ level while the lowest value is observed in the control sample. In a study conducted by Delfani et al., (2014), the damage of plasma membrane was low for iron and nanoscale iron particles in the presence of magnesium, and the lowest amount of damage with $27.9 \%$ was observed for nanoscale iron particles with magnesium at $0.25 \mathrm{~g} \mathrm{~L}^{-1}$.

As shown in Table 3, the use of iron sources can changes the total chlorophyll content of the plant. In addition, the foliar use of iron sources considerably influenced on increasing the chlorophyll content. The highest value of chlorophyll was observed for the foliar use of monodisperse iron oxide nanoparticles at $0.25 \mathrm{~g}$ $\mathrm{L}^{-1}$. The results of Ghafari and Razmjoo (2013)' study is in line with the results of the present study as they reported the application of iron oxide nanoparticles on chlorophyll a, chlorophyll b and total chlorophyll in wheat plant showed a significant increase, compared to the control sample.

4.2.2. The effect of iron sources on plant micronutrients

Table 4 indicates $0.270 \mathrm{mg} \mathrm{kg}^{-1}$ for Fe concentration in plant shoots when fertilization is performed with polymeric iron oxide nanoparticles. Based on the results, an increase occurred in the Fe concentration in plant shoot in soil use of iron sources including mono- 
dispersed iron oxide and polymeric monodisperse iron oxide nanoparticles. In addition, the same result was observed in foliar application when monodisperse iron oxide nanoparticles, polymeric iron oxide nanoparticles, and iron oxide nanoparticles were used. The results are consistent with the results of the previous studies (Márquez-Quiroz et al., 2015; Hernández-Castro et al., 2015) in which fertilizing with iron sources could significantly improves the Fe concentration in cowpea plant. In the greenhouse experiment, it was reported that some of polymeric hydrated sources provides small environment within the root zone which keeps Iron sulfate available to plants compared with its non- polymeric use (Mikkelsen, 1994). The use of polymers to supply nutrients may provide more exact conditions for the needs of the plant, while one should regard the protection of the quality of the environment and the preservation of natural resources (Mikkelsen, 1994).

In addition, Table 4 lists the results related to the effect of using different iron sources on the concentrations of other micronutrients. In spraying iron sources, the least amount of concentration in manganese in shoot $\left(3.37 \mathrm{mg} \mathrm{kg}^{-1}\right)$ was achieved after using iron oxide nanoparticles at the iron level of $0.5 \mathrm{~g} \mathrm{~L}^{-1}$. The findings of the present study are congruent with the results of previous studies. Ghasemi-Fasaei et al., (2005) demonstrated that foliar or soil applications of iron reduce the manganese of shoots, due to the antagonistic relationship of iron on absorption and transmission of manganese from root to the shoots.

Further, based on the results in Table 4, the soil use of polymeric monodisperse iron oxide nanoparticles leads to a significant increase in $\mathrm{Mn}$ concentration in plant shoot. Roosta et al. (2015) reported that the highest amount of manganese was observed in shoots of lettuce and in a variety of iceberg and iron nano-chelates treatment and this amount of manganese in leaves was significantly affected by plant varieties and their interaction with iron resources.

$\mathrm{Zn}$ content could increase by 2.87 times when $0.5 \mathrm{~g}$ $\mathrm{L}^{-1}$ iron oxide nanoparticles was used as iron source, compared to the control sample including the highest value of $\mathrm{Zn}$ in plant shoot among all the samples. In addition, monodisperse iron oxide nanoparticles caused an increase in $\mathrm{Zn}$ content of the plant shoot at the same level of iron fertilization. Further, polymeric iron oxide nanoparticles source resulted in decreasing the $\mathrm{Zn}$ content of the plant shoot (Table 4). Roosta et al., (2015) concluded that the amount of zinc and iron of leaves were significantly affected by plants varieties and their interactions with sources of iron and the highest amount of zinc was found in shoot of lettuce in iceberg varieties and iron nano chelate treatment. The findings are consistent with the results of the present research.

As shown in Table 5, regarding the related data for $\mathrm{Cu}$ micronutrient, the highest amount of $\mathrm{Cu}$ was obtained after using of $0.25 \mathrm{~g} \mathrm{~L}^{-1}$ of polymeric monodispers iron oxide nanoparticles. However, no significant difference in $\mathrm{Cu}$ content was observed in other samples, compared to the control sample. These results are congruent with Broschat and Moore (2004)'s study who showed that FeEDTA and FeEDDHA have increased the amount of copper of African marigolds leaves, but other sources failed to have consistent effect on the amount of copper of leaves.

As displayed in Table 5, the use of polymeric monodispers iron oxide nanoparticles at $0.25 \mathrm{~g} \mathrm{~L}^{-1} \mathrm{Fe}$ content in the plant root could significantly increased by $48.85 \%$ (Table 5). The results were congruent with the study of Armin et al. (2014) and Márquez-Quiroz et al. (2015). In addition, the foliar use of this iron source resulted in increasing iron absorption of root from soil. Further, based on the results in Table 3, plasma membrane damage was observed in the root PMSI in this sample which is regarded as the reason 
for improving the permeability of cellular membrane (Blume and Ebercon, 1981).

As shown in Table 5, the soil use of iron oxide nanoparticles at 0.405 and $0.270 \mathrm{mg} \mathrm{kg}^{-1}$ can decrease the amount of $\mathrm{Fe}$ and $\mathrm{Mn}$ of roots by $99.66 \%$ and $51.63 \%$, respectively. Regarding the main reason, we can refer to quick growth in plant, i.e. dry weight gain from 0.56 in control group to 2.53 and $2.19 \mathrm{~g} \mathrm{pot}^{-1}$ for the iron and manganese in iron oxide nanoparticles, respectively, which is justified by the dilution effect at the root (Feil et al., 2005). In addition, the use of iron sources leads to an increase in the Mn content in roots (Table 5). The results were consistent with the results reported by Roosta et al. (2015).

As displayed in Table 5, the $\mathrm{Zn}$ content in roots is influenced by nanostructured fertilizers. The soil application of $0.270 \mathrm{mg} \mathrm{kg}^{-1}$ in monodisperse iron oxide nanoparticles caused an increase of 10.85 times in the $\mathrm{Zn}$ content of the root plant, compared to the control sample. The least concentration of $\mathrm{Zn}$ was observed for $0.405 \mathrm{mg} \mathrm{kg}^{-1}$ in monodisperse iron oxide nanoparticles. The decrease occurred by an increase in the iron fertilizer concentration is related to dilution since dry weight increase from 0.56 in the control sample to 2.27 gram in pot in monodisperse iron oxide nanoparticles usually leads to a decrease due to the effect of dilution (Feil et al., 2005).

\section{Conclusion}

The present study aimed to evaluate the effect of iron oxide nanoparticles embedded in polymeric matrix on the physiologic characteristics of speedfeed sorghum and plasma membrane stability index (PMSI). To this aim, some iron oxidesources including iron oxide nanoparticles, monodisperse iron oxide nanoparticles, polymeric iron oxide nanoparticles and polymeric monodisperse iron oxide nanoparticles were examined. Based on the results, polymeric monodisperse iron oxide nanoparticles prepared by using polymer leads to a significant increase in total chlorophyll, the PMSI of roots and shoots, $\mathrm{Zn}$ and $\mathrm{Fe}$ contents of shoots, as well as $\mathrm{Cu}$ and $\mathrm{Fe}$ contents in roots. The result of the present study can pave the way for further investigation on novel nanostctured nutritients in order to improve growth parameters of plants.

\section{Acknowledgements}

The authors would like to thank the referees for their valuable suggestions and the Deputy of Research of Zabol University for provding financial support in this research under a project No: UOZ-GR-9517-20.

\section{References}

Armin, M., Akbari, S., Mashhadi, S. 2014. Effect of time and concentration of nano-Fe foliar application on yield and yield components of wheat. International Journal of Biosciences. 4, 69-75.

Arnon, D.I. 1949. Copper Enzymes in Isolated Chloroplast, Polyphenol Oxidase in Beta vulgaris. Journal Plant Physiol. 24, 1-75.

Bityutskii, N., Yakkonen, K., Petrova, A., Nadporozhskaya, M. 2017. Xylem sap mineral analyses as a rapid method for estimation plant-availability of $\mathrm{Fe}, \mathrm{Zn}$ and $\mathrm{Mn}$ in carbonate soils: a case study in cucumber. Journal of Soil Science and Plant Nutrition. 17, 279-290.

Blume, A., Ebercon, A. 1981. Cell membrane stability as a measure of drought and heat tolerance in wheat. Crop Sci. 27, 43-47.

Borowski, E., Michalek, S. 2011. The effect of foliar fertilization of French bean with iron salts and urea on some physiological processes in plants relative to iron uptake and translocation in leaves. Acta Sci. Pol. Hortorum Cultus. 10, 183-193. 
Bouyoucos, C.J. 1997. Hydrometer method improved for making particle size analysis of soil. Agronomy Journal. 54, 464-465.

Broschat, T.K., Moore, K.K. 2004. Phytotoxicity of several iron fertilizers and their effects on $\mathrm{Fe}, \mathrm{Mn}$, $\mathrm{Zn}, \mathrm{Cu}$, and $\mathrm{P}$ content of African Marigolds and Zonal Geraniums. Hort. Science. 39, 595-598.

Delfani, M., Baradarn Firouzabadi, M., Farrokhi, N., Makarian, H. 2014. Some Physiological Responses of Black-Eyed Pea to Iron and Magnesium Nanofertilizers. Communications in Soil Science and Plant Analysis. 45, 530-540.

Dang, T. M. D., Le, T. T. T., Fribourg-Blanc, E., Dan, M. C. 2011. Synthesis and optical properties of copper nanoparticles prepared by a chemical reduction method. Adv. Nat. Sci.: Nanosci. Nanotechnol. 2, 015009.

Dong, Y.J., He, M.R., Wang, Z.L., Chen, W.F., Hou, J., Qiu, X.K., Zhang, J.W. 2016. Effects of new coated release fertilizer on the growth of maize. Journal of Soil Science and Plant Nutrition. 16, 637-649.

Feil, B., Moser, S.B., Jampatong, S., Stamp, P. 2005. Mineral composition of the grains of tropical maize varieties as affected by preanthesis drought and rate of nitrogen fertilization. Crop Sci. 45, 516-523.

Ghafari, H., Razmjoo, J. 2013. Effect of Foliar Application of Nano-iron Oxidase, Iron Chelate and Iron Sulphate Rates on Yield and Quality of Wheat. Intl. J Agron Plant Prod. 4, 2997-3003.

Ghafariyan, M.H., Malakouti, M.J., Dadpour, M.R., Stroeve, P., Mahmoudi, M. 2013. Effects of Magnetite Nanoparticles on Soybean Chlorophyll. Environ. Sci. Technol. 47, 10645-10652.

Ghasemi-Fasaei, R., Ronaghi, A., Maftoun, M., Karimian, N., Soltanpour, P.N. 2005. Iron-Manganese Interaction in Chickpea as Affected by Foliar and Soil Application of Iron in a Calcareous Soil. Commun. Soil Sci. Plant Anal. 36, 1717-1725.
Godsey, R. J., Johnson, B. 2001. Seed treatment, seeding rate, and cultivar effects on iron deficiency chlorosis of soybean. Journal of Plant Nutrition. 24, 1255-1268.

Helmke, P.A., Sparks, D.L. 1996. Lithium, sodium, potassium, cesium, and rubidium. In: D.L. Sparks (ed.). Methods of soil analysis: Part 3. Chemical methods and processes. Madison, Soil Science Soc., 551-574.

Hernández-Castro, E., Trejo-Téllez, L.I., Gómez-Merino, F.C., Rodríguez-Mendoza, M.N., SánchezGarcía, P., Robledo-Paz, A. 2015. Bioaccumulation of iron, selenium, nitrate, and proteins in chard shoots. Journal of Soil Science and Plant Nutrition. 15, 694-710.

Korcak, R.F. 1987. Iron Deficiency Chlorosis. Hort. Rev. 9, 133-186.

Levitt, J. 1980. Responses of plants to environmental stress: Water, Radiation, Salt and Other Stresses, Vol. II, Academic Press, NewYork, pp: 3-211.

Lindsay, W.L., Norvell, W.A. 1978. Development of DTPA Soil test for Zinc, Iron, Mangnese and Copper. Soil Sci. Society of American Journal. 42, 421-428.

Lucena, J.J. 2006. Synthetic iron chelates to correct iron deficiency in plants. In: L.L. Barton, J. Abadía (eds.). Iron nutrition in plants and rhizospheric microorganisms. Springer, Dordrecht, pp: 103-128.

Márquez-Quiroz, C., De-la-Cruz-Lázaro, E., OsorioOsorio, R., Sánchez-Chávez, E. 2015. Biofortifcation of cowpea beans with iron: iron's influence on mineral content and yield. Journal of Soil Science and Plant Nutrition. 15, 839-847.

Mikkelsen, R.L. 1994. Using hydrophilic polymers to control nutrient release. Fertilizer Research. $38,53-59$. 
Motsara, M.R., Roy, R.N. 2008. Guide to laboratory establishment for plant nutrient analysis: Plant analysis. Food and Agriculture Organization of the United Nations. Pp. 80.

Olsen, S.R., Cole, C.V., Watanabe, F.S., Dean, L.A. 1954. Estimation of available phosphorus in soils by extraction with sodium bicarbonate. USDA Circular 939, US Gov. Printing Office, Washington, DC.

Page, A.L., Miller, R.H., Keeney, D.R. 1982. Methods of soil analysis. Part 2. 2nd Ed. ASA and SSSSA. Madison, WI.

Rezaeei, M., Daneshvar, M., Shirani, A.H. 2014. Effect of iron nano chelated fertilizers foliar application on three wheat cultivars in Khorramabad climatic conditions. Scientific Journal of Crop Science. 3. 9-16.

Rible, J.M., Quick, J. 1960. Method S-19.0. In: Water soil plant tissue. Tentative methods of analysis for diagnostic purposes. Davis, University of California Agricultural Experiment Service. Mimeographed Report.

Rico, C.M., Majumdar, S., Duarte-Gardea, M., Peralta-Videa, J.R., Gardea-Torresdey, J.L. 2011. Interaction of nanoparticles with edible plants and their possible implications in the food chain. J. Agric. Food Chem. 59, 3485e3498.

Roosta, H.R., Jalali, M., Vakili Shahrbabaki, S.M.A. 2015. Effect of Nano Fe-Chelate, Fe-EDDHA and FeSO4 on Vegetative Growth, Physiological Parameters and Some Nutrient Elements Concentrations of Four Varieties of Lettuce (Lactuca sativa L.) In NFT System. Journal of Plant Nutrition. 38, 2176-2184.

Sairam, R.K., Srivastava, G.C. 2001. Water stress tolerance of wheat (Triticum astivum L.): Variation in hydrogen peroxide accumulation and antioxi- dant activity in tolerant and susceptible genotype. Journal of Agronomy and Crop Science. 186, 63-70.

Seeger, E.M., Baun, A., Kastner, M., Trapp, S. 2009. Insignificant acute toxicity of $\mathrm{TiO}_{2}$ nanoparticles to willow trees. J. Soils Sediments. 9, 46e 53.

Sheykhbaglou, R., Sedghi, M., Tajbakhsh shishevan, M., Sharifi S.R. 2010. Effects of nano-iron oxide particles on agronomic traits of soybean. Notulae Sci Bio. 2, 112-113.

Sullivan, C.Y. 1972. Mechanism of heat and drought resistance in grain sorghum and method of measurement. In: RAO, N.G.P. and L.R. House (eds.). Sorghum in seventies. Oxford and IBH publishing company, New Delhi. pp: 247-246.

Sullivan, C.Y., Ross, W.M. 1979. Selecting for drought and heat resistance in grain sorghum. In: H., Mussel, Staples, R.C. (eds.). Stress physiology in crop plants. John Wiely and Sons, NewYork. pp. 263-281.

U.S. Salinity Laboratory Staff. 1954. Alkaline-earth carbonates by gravimetric loss of carbon dioxide. In: L. A. Richards (ed.). Diagnosis and improvement of saline and alkali soils. USDA Agric. Handbook. 60. U.S. Government Printing Office, Washington, D.C. p. 105.

Walkley, A., Black, I.A. 1934. Chromic acid titration for determination of soil organic matter. Soil Science. 63, 251.

Wang, Q., Ebbs, S.D., Chen, Y.S., Ma, X.M. 2013. Trans-generational impact of cerium oxide nanoparticles on tomato plants. Metallomics. 5 (6), $753 \mathrm{e} 759$. 